The Digital Object Identifier - DOI: 10.37952/ROI-jbc-01/20-64-11-42

Submitted on November 18, 2020.

Thematic course: Synthesis, structure and properties of new potentially biologically active derivatives. Part 5.

\title{
Squalene interactions with some hydrosilanes and hydrogermans
}

\author{
C Dmitry A. Efimenko, ${ }^{1}$ Irina B. Sokolskaya, ${ }^{1}$ Evgeny N. Oficerov, ${ }^{2}{ }^{+}$ \\ Antonida V. Kalistratova, ${ }^{2}$ Mihail M. Sibircev, ${ }^{1}$ Vladislav Y. Kolesnikov, ${ }^{2}$ \\ Valentin G. Lahtin, ${ }^{1}{ }^{*}$ and Pavel A. Storozhenko ${ }^{1}$ \\ ${ }^{1}$ SSC RF JSC "GNIIChTEOS". Entuziastov Highway, 38. Moscow, 105118. Russia. \\ Phone:+7 (495)673-79-46. E-mail:vlachtin@rambler.ru \\ ${ }^{2}$ Department of Chemistry and Technology of Biomedical Preparations. Faculty of Chemical and \\ Pharmaceutical Technologies and Biomedical Products. D. Mendeleev University of Chemical Technology \\ of Russia. Miusskaya Sq.9. Moscow, 125047.Russia.Phone: +7 (495) 978-32-61.E-mail: ofitser@mail.ru
}

\section{*Supervising author; ${ }^{+}$Corresponding author}

Keywords: squalene, vinyltrimethylsilane, tetramethyldisiloxane, silyl hydride, hydrosilylation, Karstedt's catalyst, adduct, NMR spectroscopy.

\section{Abstract}

Squalene hydrosilylation by a number of organohydrosilanes $\mathrm{R}_{3} \mathrm{SiH}$ and $\mathrm{Me}_{3} \mathrm{GeH}$, including a mixture of $\alpha$ - and $\beta$-isomers of adducts of vinyltrimethylsilane addition to tetramethyldisiloxane: $\mathrm{HSi}\left(\mathrm{Me}_{2}\right) \mathrm{O}\left(\mathrm{Me}_{2}\right) \mathrm{Si}$ $\mathrm{C}(\mathrm{Me})-\mathrm{SiMe}_{3}$ and $\mathrm{HSi}\left(\mathrm{Me}_{2}\right) \mathrm{O}\left(\mathrm{Me}_{2}\right) \mathrm{Si}-\left(\mathrm{CH}_{2}\right)_{2}-\mathrm{SiMe}_{3}$, formed both according to Markovnikov's rule and against it, is discussed. We pay attention to the mismatch of values between the electronegativities of carbon, silicon, germanium and hydrogen atoms and the reactivity of $\mathrm{C}-\mathrm{H}, \mathrm{Si}-\mathrm{H}$, and $\mathrm{Ge}-\mathrm{H}$ bonds. A spectral study of a mixture of $\alpha$ - and $\beta$-isomers was carried out. The effect of substituents at elements on its reactivity is discussed: hydrosilanes with chlorine atoms, alkyl and alkoxy groups on silicon are not active in the squalene hydrosilylation. In contrast to them, the $\alpha$ - and $\beta$-adducts and their mixture add well to squalene with an unambiguously unknown regioselectivity. The results obtained indicate the special behavior of squalene in electrophilic addition reactions catalyzed by metal complexes, in contrast to substituted ethylenes.

\section{References}

[1] M. Micera, A. Botto, F. Geddo, et.al. Squalene: More than a Step toward Sterols. Antioxidants. 2020. Vol.9. No.8. P.688.

[2] M. Spanova, \& G. Daum. Squalene-biochemistry, molecular biology, process biotechnology, and applications. European journal of lipid science and technology. 2011. Vol.113. No.11. P.1299-1320.

[3] C. Gabás-Rivera, C. Barranquero, R. Martínez-Beamonte, M.A. Navarro, J.C. Surra, \& J. Osada. Dietary squalene increases high density lipoprotein-cholesterol and paraoxonase 1 and decreases oxidative stress in mice. PloS one. 2014. Vol.9. No.8. e104224.

[4] D.H. Shin, H.J. Heo, Y.J. Lee, \& H.K. Kim. Amaranth squalene reduces serum and liver lipid levels in rats fed a cholesterol diet. British Journal of Biomedical Science. 2004. Vol.61. No.1. P.11-14.

[5] J.A. Dunn, J.C. Prickett, D.A. Collins, R. Macarthur, \& R.J. Weaver. Choice test to determine potential attractants and repellents for the sheep scab mite, Psoroptes ovis (Acari: Psoroptidae). Experimental and Applied Acarology. 2019. Vol.79. No.2. P.187-194.

[6] Z.R. Huang, Y.K. Lin, \& J.Y. Fang. Biological and pharmacological activities of squalene and related compounds: potential uses in cosmetic dermatology. Molecules. 2009. Vol.14. No.1. P.540-554.

[7] K. Wołosik, M. Knaś, A. Zalewska, M. Niczyporuk, \& A.W. Przystupa. The importance and perspective of plant-based squalene in cosmetology. Journal of cosmetic science. 2013. Vol.64. No.1. P.59.

[8] Yu.V. Shchepotkina, E.N. Oficerov, Yu.V. Borzova. Influence of microwave radiation on the process of hydrolytic extraction of amaranth oil in the presence of potassium hydroxide. Advances in chemistry and chem. technologies. 2010. Vol.24. No.6. P.19-21. (russian)

[9] A.V. Fursova and E.N. Ofitserov. Inhibition of squalene biosynthesis and metabolism. Butlerov Communications. 2011. Vol.25. No.7. P.50-75. ROI-jbc-02/11-25-7-11 
[10] D. Desmaële, R. Gref, P. Couvreur. Squalenoylation: a generic platform for nanoparticular drug delivery. Journal of controlled release. 2012. Vol.161. No.2. P.609-618.

[11] A.V. Kalistratova, A.T. Teleshev, and E.N. Ofitserov. Supramolecular complexes of squalene in electrophilic addition. Butlerov Communications. 2014. Vol.39. No.10. P.121-126. ROI-jbc-02/14-39$10-121$

[12] V.G. Lakhtin, I.B. Sokolskaya, E.N. Ofitserov, I.A. Nilov, A.V. Kalistratova, N.V. Ushakov, N.G. Komalenkova, and P.A. Storozhenko. Synthesis of some organosilicon derivatives of squalene. Butlerov Communications. 2017. Vol.52. No.12. P.61-72. DOI: 10.37952/ROI-jbc-01/17-52-12-61

[13] M.A. Brook, A. Ragheb. Oxidizable coupling agents: introduction of surface functionality. The Journal of Adhesion. 2002. Vol.78. P.521-541

[14] S.D. Vlasenko. Synthesis, properties and application of vinylsilanes and their adducts with hydrosilanes: diss. Cand. chem. Sciences: 02.00.08. M. 1983. 177p. (russian)

[15] B. Marciniec. Comprehensive handbook on hydrosilylation: Oxford-New/York: Pergamon Press. 2002. $754 \mathrm{p}$. 